\title{
STEFFENSEN-GRÜSS INEQUALITY
}

\section{SAAD I. BUtT, MiliCA KLARIČIĆ BAKUlA* AND Josip PEČARIĆ}

Abstract. Two inequalities for the Jensen difference under Steffensen's conditions with Grüss type upper bounds are proved.

Mathematics subject classification (2020): 26 D15.

Keywords and phrases: Jensen-Steffensen inequality, Jensen-Mercer inequality, Grüss inequality.

\section{REFERENCES}

[1] S. Abramovich, M. Klaričić Bakula, M. Matić, J. Pečarić, A variant of Jensen-Steffensen's inequality and quasi-arithmetic means, J. Math. Anal. Appl. 307 (2005), no. 1, 370-386.

[2] I. Budimir, J. PeČArić, The Jensen-Grüss inequality, Math. Inequal. Appl. 5 (2002), no. 2, 205214.

[3] M. KlaRiČIĆ BAKUla, J. PEČARIĆ, On the pre-Jensen-Grüss inequality, Mathematical Inequalities and Applications, Vol. 23, Issue 4 (2020), 1529-1543.

[4] D. S. Mitrinović, E. J. PeČArić, A. M. Fink, Classical and new inequalities in analysis, Mathematics and its Applications (East European Series), 61. Kluwer Academic Publishers Group, Dordrecht, 1993.

[5] A. M. Ostrowski, On an integral inequality, Aequationes Math. 4 (1970), 358-373.

[6] Josip E. PEČARIĆ, On the Ostrowski generalization of Čebyšev's inequality, J. Math. Anal. Appl. 102 (1984), no. 2, 479-487.

[7] Josip E. PeČarić, Frank Proschan, Y. L. Tong, Convex functions, partial orderings, and statistical applications, Mathematics in Science and Engineering, 187. Academic Press, Inc., Boston, MA, 1992.

[8] J. F. StefFensen, On certain inequalities and methods of approximation, J. Inst. Actuaries, 51 (1919), 274-297. 